\title{
Erratum: Application of Modeling Approaches to Explore Vaccine Adjuvant Mode-of-Action
}

\author{
Frontiers Production Office* \\ Frontiers Media SA, Lausanne, Switzerland
}

Keywords: vaccines, adjuvants, mathematical modeling, computational biology, systems biology, mechanistic modeling, AS01

\section{An Erratum on}

Application of Modeling Approaches to Explore Vaccine Adjuvant Mode-of-Action

\section{OPEN ACCESS}

Approved by:

Frontiers Editorial Office,

Frontiers Media SA, Switzerland

*Correspondence:

Frontiers Production Office production.office@frontiersin.org

Specialty section:

This article was submitted to Vaccines and Molecular Therapeutics,

a section of the journal

Frontiers in Immunology

Received: 25 November 2019 Accepted: 26 November 2019

Published: 02 December 2019

Citation:

Frontiers Production Office (2019)

Erratum: Application of Modeling

Approaches to Explore Vaccine

Adjuvant Mode-of-Action.

Front. Immunol. 10:2905

doi: 10.3389/fimmu.2019.02905 by Buckley, P. R., Alden, K., Coccia, M., Chalon, A., Collignon, C., Temmerman, S. T., et al. (2019).

Front. Immunol. 10:2150. doi: 10.3389/fimmu.2019.02150

Due to a production error, the author "Margherita Coccia" was not added in the Conflict of Interest Statement. The correct statement should read:

"CA, RM, AD, MC, and ST report ownership of GSK shares and/or restricted GSK shares."

Furthermore, there is a typo in the city of Affiliation 4. Instead of "Faculty of Technology, University of Sunderland, Sunderlandm, United Kingdom" it should be "Faculty of Technology, University of Sunderland, Sunderland, United Kingdom."

Lastly, the caption provided in Figure $\mathbf{S 1}$ is incorrect. The correct caption should read:

"Figure S1. The CellDesigner Model captures the following key compartments: the muscle injection site (A), the lymphatic vessels (B), the draining lymph node (dLN) [including paracortex (C), B cell follicles (D), germinal center (E)], the blood (F), and the bone marrow (G). This model captures high-level mechanisms that are hypothesized to give rise to the phenomena observed by experimentation in mice. This begins with the intramuscular injection (34) of the vaccine at time zero (A) and captures the events leading to the secretion and circulation of antibodies (E,F), and lymph node egression of effector memory T cells (9)."

The publisher apologizes for these mistakes. The original article has been updated.

Copyright $\odot 2019$ Frontiers Production Office. This is an open-access article distributed under the terms of the Creative Commons Attribution License (CC BY). The use, distribution or reproduction in other forums is permitted, provided the original author(s) and the copyright owner(s) are credited and that the original publication in this journal is cited, in accordance with accepted academic practice. No use, distribution or reproduction is permitted which does not comply with these terms. 